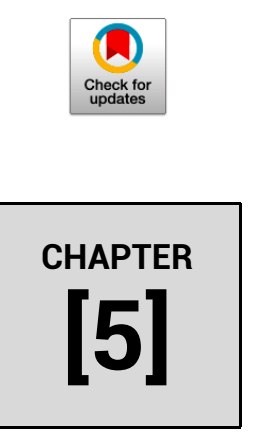

In: Environmental Degradation: Causes and Remediation Strategies

DOI: 10.26832/aesa-2020-edcrs-05

\title{
Integration of treated agro-based wastewaters (TAWs) management with mushroom cultivation
}

\author{
Vinod Kumar ${ }^{1}$, Madhumita Goala ${ }^{2}$, Pankaj Kumar ${ }^{1, *}$, \\ Jogendra Singh ${ }^{1}$, Piyush Kumar ${ }^{1}$ and Sonika Kumari ${ }^{1}$ \\ ${ }^{1}$ Agro-ecology and Pollution Research Laboratory, Department of Zoology and Environmental Science, \\ Gurukula Kangri Vishwavidyalaya, Haridwar-249404 (Uttarakhand), India \\ ${ }^{2}$ Nehru College, Assam University, Labocpar Part II, Cachar 788098 (Assam), India
}

ABSTRACT

The inefficient management of wastewater generated from agro-based industries has become a cause of environmental degradation. Treated agrobased wastewaters (TAWs) are characterized by higher nutrients load and therefore, utilizable in the agriculture and horticulture as irrigation source. Agricultural reuse of TAWs is the most common practice done by the farmers of developing countries. Using freshwater for substrate wetting has been creating an extra load on our drinking water resources. Globally, a huge volume of freshwater is utilized for substrate formulation in the commercial mushroom cultivation and integration of TAWs with mushroom cultivation has presented improvements in the mushroom productivity, signifying their cultivation more profitable. Furthermore, spent substrates can be used for biogas production, animal feed for mature castrated male sheep, post-weaning calves feeding, biodiesel production, bioethanol production, reducing sugar production, biofertilizer production, methane production, butanol production, etc. This book chapter deals with sustainable approaches to the potential use of TAWs in the formulation of mushroom's substrate material along with efficient management of spent mushroom substrate.

KEYWORDS

Bioremediation, Industrial wastewaters, Mushroom cultivation, Water usage

Pankaj Kumar, Email: kumarpankajgkv@gmail.com

(C) 2020 | Agro Environ Media | Agriculture and Environmental Science Academy, Haridwar, India 


\section{Introduction}

Mushrooms are macro-fungi existing on the earth for 300 million years. As a foremost part of animal nutrition, they have been a good source of food and medicinal products (Valverde et al., 2015; Royse et al., 2017). Most of the edible and medicinal mushrooms can be grown on the selective type of agricultural wastes including, manure, sawdust, hardwood, soy hulls, wheat straw, rice straw, corn husk, peanut husk, wood lodges, mustard stem, crop leaves, and sugarcane bagasse, etc. (Grimm and Wösten, 2018). These substrates are known as bulk mushroom substrates and need further processing (nutrients addition) before application in the commercial cultivation. However, a substrate having specific and optimum contents of nitrogen, carbon, and minerals may be supportive for maximizing the growth and yield performance of mushroom as they can be easily broken assimilated by fungal mycelia (Bellettini et al., 2016). Therefore, substrate formulation is the first step in commercial mushroom cultivation which involves adjusting its nutrient content easily utilizable by mushrooms (Carrasco et al., 2018). For this, mushroom substrate/compost technology offers agricultural waste management through utilization as feedstock for large-scale mushroom production (Gyenge et al., 2016). Substrate formulation is achieved in a series of substantial steps such as substrate cutting, grinding, wetting, fertilizing, composting followed by pasteurization and sterilization. Sufficient water content in the substrate is essential for mushroom growth, therefore, freshwater is essentially used to wet the mushroom substrates commonly known as substrate wetting. It is estimated nearly 200 liters of fresh water are used to produce $1 \mathrm{Kg}$ of white button mushroom (Udom et al., 2016). Using freshwater for substrate wetting has been creating an extra load on our drinking water resources, therefore, there is a new interest in developing more efficient substrate formulating technologies by using treated agro-based wastewaters (TAWs) as an alternative of freshwater (Kalmış et al., 2002; Kalmıs et al., 2008; Avni et al., 2017; Chang and Wasser, 2018).

Various agro-based industries such as sugar mill, palm mill, distillery, sago, oil-producing, dairy, food processing, molasses-based alcohol and beverages, tea and coffee, crop product processing, and biofertilizer producing industries are known to generate highly nutritive and less toxic wastewaters (Rebah et al., 2007; Rattan et al., 2015; Sadh et al., 2018). The treated agro-based wastewaters (TAWs) have been recognized for their irrigational application in horticulture and agriculture (Kretschmer et al., 2002; Shuval, 2012). The nutrient content accumulated in the agricultural soils after irrigating with such TAWs helps to enhance the growth and productivity of crop plants. It is estimated that nearly $20 \%$ of Mexico, $26 \%$ of Pakistan, $30 \%$ of India, $50 \%$ of Ghana, and $80 \%$ of Hanoi's agricultural land is being irrigated with both treated and untreated wastewaters generated from municipal and industrial sectors (Pedrero et al., 2010).

The idea of integrating TAWs with mushroom cultivation is not new but only a few reports 
(Kalmis et al., 2008; Avni et al., 2017; Chang and Wasser, 2018) are currently available focusing on this aspect, therefore, it requires more attention for scientific exploration. The views in previously published reports deal with either utilizing such as TAWs for wetting mushroom substrate or blending some agro-based solid wastes with the mushroom substrate. However, not all kinds of wastewaters can be used for wetting the substrates, but only a few TAWs are suitable to formulate the substrate materials of both edible and semi-edible mushroom species. Following the above aspects, this book chapter focused on the potential utilization of TAWs with agricultural wastes to grow mushrooms and further management of the spent substrate.

\section{Waste decomposition and nutrients utilization by mushrooms}

The main carbon and nitrogen sources required for the growth of mushroom comes from dead animal and plants (lignocellulosic) biomasses (Sánchez, 2009). Nevertheless, dead animal and lignocellulosic biomasses have never been exhausted on the earth assisting mushrooms to be one of the most primitive and successful organisms. The growth of a mushroom is divided into two phases including spawn running or mycelium growth followed by flush production or vegetative growth where actual biomass is produced (Montoya et al., 2012; Bellettini et al., 2016). During the mycelium growth phase, the fungal spores start propagating and spreading over the substrate surface creating a threadlike network system. This mycelium network covers the substrate surface and secrets a number of extracellular enzymes resulting in the degradation of lignin and cellulose (Table 1 and Figure 1).

Table 1. Mechanisms and enzymes involved in ligninolytic and non-ligninolytic substrate degradation by mushrooms.

\begin{tabular}{|c|c|c|}
\hline Substrate type & Enzyme(s) involved & Degradation mechanism(s) \\
\hline \multirow[t]{4}{*}{ Ligninolytic } & Phenoloxidases & $\begin{array}{l}\text { Hydroxylation, free radical } \\
\text { action, mediator }\end{array}$ \\
\hline & Peroxidases & $\begin{array}{l}\text { Production of quinones } \\
\text { followed by ring fission }\end{array}$ \\
\hline & Glucoseoxidases & $\begin{array}{l}\text { Production of hydrogen } \\
\text { peroxide }\end{array}$ \\
\hline & Methyltransferase & $\begin{array}{l}\text { Methylation of the carboxyl } \\
\text { group }\end{array}$ \\
\hline \multirow[t]{3}{*}{ Non-ligninolytic } & $\begin{array}{l}\text { Aryl alcohol oxidase, Alde- } \\
\text { hyde reductase }\end{array}$ & $\begin{array}{l}\text { Production of aldehydes and } \\
\text { alcohols }\end{array}$ \\
\hline & Cytochrome P450 & Hydroxylation \\
\hline & Cellobiose dehydrogenase & Fenton reaction \\
\hline
\end{tabular}




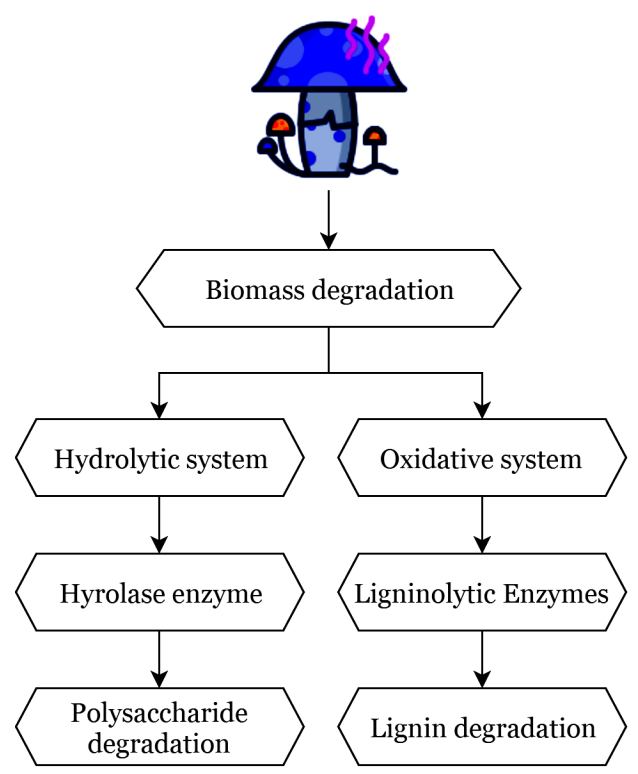

Figure 1. Mechanisms of lignocellulosic biomass degradation used by mushrooms.

The secretion of various intracellular and extracellular enzymes like peroxidases, ligninase, peroxidase, manganese, cellulases, pectinases, xylanases, and oxidases help them to breakdown the dead organic matter and convert them to lesser molecular and ionic forms which can be easily utilized by mushroom during its vegetative growth (Sánchez, 2009). Besides this, the process of breakdown is composite where multiple enzymes act to remediate a molecule from high molecular weight to low. These enzymes are induced by cytochrome P450 gene of fungi which have both ligninolytic and non-ligninolytic degradation capabilities (Kulshreshtha et al., 2014).

The nutrients, ions, and water contents are transported from substrate to mushroom body by means of both active and passive mechanisms (Smith, 1984; Randive, 2012). Specific physical and biochemical responses and stabilization for various nutrients in the mushroom are accomplished by myco-degradation, myco-stabilization, and myco-stimulation by mycelia, while bioaccumulation and myco-volatilization by the mushroom body (Chanda et al., 2016). However, certain abiotic and biotic factors such as temperature, humidity, relative substrate moisture, luminescence, atmospheric pressure, substrate $\mathrm{pH}$, electrical conductance, available energy as carbon/nitrogen contents, minerals, interacting pests and pathogens, etc. may affect the nutrient transfer mechanism of mushrooms (Kulshreshtha et al., 2014).

There is an ultimate requirement of several micro and macronutrients for mushroom growth. In this regard, metal ions are transported to the mushroom body in the form of a metal-enzyme 
complex. The process involves two sequential steps i.e. ion regulation and ion uptake in which certain fungal genes such as Vps, Rbt, Ftr, Fet, Fre, Sit, Zrt, Pho84, etc. The genes help in secreting the extracellular enzymes which help to bind and transport them into the fungal cell wall. However, these genes may vary according to the mushroom species. Therefore, there is an essential requirement metal ion in mushroom growth and virulence (Gerwien et al., 2017). Besides this, the $\mathrm{C} / \mathrm{N}$ content of the substrate strongly regulates the decomposition process by mushrooms. It has been reported in recent studies that the amendment of $\mathrm{C} / \mathrm{N}$ rich substrates and fertilizers actively affects the rates of substrate breakdown and further nutrient uptake (Migliore et al., 2012; Kumar et al., 2019).

\section{Nutrient values of treated agro-based wastewaters (TAWs)}

Even after secondary treatment of wastewater from agro-based industries, a non-negligible amount of such utilizable nutrients is left. Despite, farmers prefer to use them as irrigation water due to their high nutrient values which results in rapid soil fertilization and high crop yields (Gothwal et al., 2012). It is found that long term soil irrigation using treated wastewaters having has shown excessive micronutrient accumulation, which affects microbial diversity and plant growth. However, mixing these TAWs with the mushroom substrate is a one-time practice, therefore, lesser will be the chances of excessive micronutrient accumulation. Below are the elementary nutrient values of TAWs which makes them useful for mushroom's substrate formulation.

Organic load: Organic content of TAWs is the total biodegradable dry biomass present in the suspended form (Kretschmer et al., 2002). The organic contents of TAWs come from the processed agro-based materials (organic compounds, complexes, microorganisms, residual biomass, etc.). Moreover, plant-based materials such as plant leaves, root, stem, fruits, juice, extracts, litter are also helpful to enrich TAWs with organic load (Kumar et al., 2018). The most common parameters of organic load are biological oxygen demand (BOD) and chemical oxygen demand (COD). Organic load of TAWs presents in both fixed and non-fixed forms which have been playing a crucial role in providing fertilizer values to the crops through wastewater irrigation. Microorganisms continuously feed and breakdown organic particles. As a result of redox reactions of microbial enzymes, these particles are converted into smaller and utilizable (by plant) molecular forms (Kwak et al., 2009). Therefore, the organic content of TAWs may be helpful in increasing the mushroom's substrate value, which may be helpful for increasing their growth and productivity.

Micronutrients: The elements required in trace quantity for life are known as micronutrients. Despite the proper functioning and metabolism of fungi, they perform an essential role in 
balanced mycelium growth. These elements include copper $(\mathrm{Cu})$, iron $(\mathrm{Fe})$, manganese $(\mathrm{Mn})$, zinc (Zn), and molybdenum (Mo). Micronutrients are the foremost part of agro-based residues. TAWs contain sufficient micronutrients that can provide fertilization to the mushroom substrate. During the raw crop processing, these micronutrients are released in the wastewater. However, a significant amount of micronutrients is removed during the wastewater treatment process, therefore, TAWs are known to have a permissible level of micronutrients suitable for irrigation (Kumar et al., 2018). These micronutrients play a critical role in microbial growth and development.

Macronutrients: Macronutrients includes nitrogen (N), calcium (Ca), magnesium (Mg), sodium $(\mathrm{Na})$, potassium $(\mathrm{K})$, and phosphorus $(\mathrm{P})$. Macronutrients essentially play an important role in fungal growth and development. $\mathrm{N}$ play role in constructing the genetic material and protein synthesis while, $\mathrm{Ca}, \mathrm{Mg}, \mathrm{K}$, and $\mathrm{P}$ have their own specified roles in various metabolic, growth, pathogen defense, and virulence (Gothwal et al., 2012). In TAWs, a significant quantity of these nutrient elements present. Higher amounts of macronutrients in discharged wastewaters may contribute essentially to fungal growth.

Other problems: Besides having the above utilizable contents, TAWs often come with numerous ion toxicity, heavy metals, microbial contamination, pesticide residues, and radioactive elements (Australia Standards, 2012). The fecal coliforms, fungi, bacteria, viruses, nematodes, protozoans are also the foremost part of discharged wastewaters.

\section{Integration of treated agro-based wastewaters (TAWs) with mushroom cultivation}

The integration of TAW with mushroom cultivation has given promising results. Agro-based substrates are supplemented with nutrients from different TAWs for enhanced mushroom productivity (Phan et al., 2012; Hanafi et al., 2018). However, there are only a few studies related to this, therefore, there is a strong need to explore the potential of certain TAWs in enhancing the nutrient values of mushroom substrates. The TAWs can be utilized as substrate moistening agents as an alternative to regular water supply (Figure 2 and Table 2). However, the substratum formulated by this method must be thoroughly sterilized before inoculated with mushroom spawn (BARC, 2018). Previously, certain experiments have been conducted to assess the effect of TAWs on mushroom productivity. Out of them, Wang et al. (2001) enhanced the efficiency of wheat straw by supplementing spent beer effluent for the cultivation of Pleurotus ostreatus mushroom. Olive mill wastewater was useful for the enrichment of wheat straw used to grow different Pleurotus sp. Kalmis and Sargin (2004). Distillery effluent was helpful for supplementation of wheat straw and bagasse used to grown three Pleurotus strains 


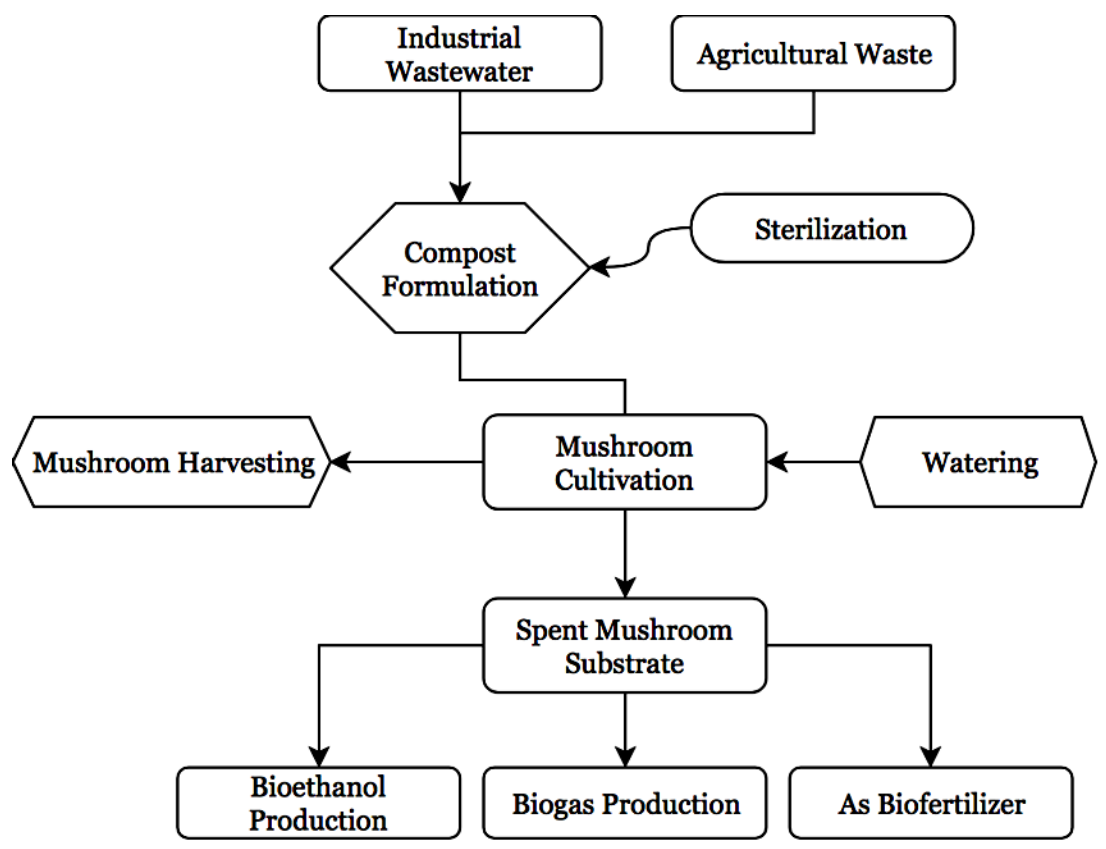

Figure 2. Integrating agro-based industrial wastewater with mushroom cultivation.

Table 2. Industrial wastewaters (effluents) used for the cultivation of mushrooms.

\begin{tabular}{|c|c|c|c|}
\hline Effluent/wastewater & Substrate & Mushroom species & Reference \\
\hline Spent beer effluent & Wheat straw & Pleurotus ostreatus & Wang et al. (2001) \\
\hline $\begin{array}{l}\text { Olive mill } \\
\text { wastewater }\end{array}$ & Wheat straw & Pleurotus sp. & Kalmis and Sargin (2004) \\
\hline Distillery effluent & Wheat straw and bagasse & $\begin{array}{l}\text { Pleurotus florida Eger } \\
\text { (EM 1303), Pleurotus } \\
\text { pulmonarius (Fries) } \\
\text { Quelet (EM 1302) and } \\
\text { Pleurotus sajor-caju } \\
\text { (Fries) Singer (EM } \\
\text { 1304) }\end{array}$ & Pant et al. (2006) \\
\hline Maize wastewater & Wheat straw & $\begin{array}{l}\text { Pleurotus ostreatus and } \\
\text { Pleurotus floridae }\end{array}$ & Loss et al. (2009) \\
\hline $\begin{array}{l}\text { Agro-food industry } \\
\text { wastes }\end{array}$ & $\begin{array}{l}\text { Wheat straw, cotton } \\
\text { waste, and peanut shelf }\end{array}$ & $\begin{array}{l}\text { Pleurotus sp., Lentinula } \\
\text { edodes }\end{array}$ & $\begin{array}{l}\text { Philippoussis and } \\
\text { Diamantopoulou (2010) }\end{array}$ \\
\hline Olive mill waste & Wheat straw & Seven Pleurotus strains & Ruiz-Rodriguez et al. (2010) \\
\hline $\begin{array}{l}\text { Distillery } \\
\text { wastewater }\end{array}$ & Sugar cane bagasse & $\begin{array}{l}\text { Pleurotus flabellatus and } \\
\text { Pleurotus sajor-caju }\end{array}$ & Gothwal et al. (2012) \\
\hline Dairy wastewater & Sugar cane bagasse & $\begin{array}{l}\text { Pleurotus flabellatus and } \\
\text { Pleurotus sajor-caju }\end{array}$ & Gothwal et al. (2012) \\
\hline $\begin{array}{l}\text { Fruit packaging } \\
\text { industry effluent }\end{array}$ & Wheat straw & Pleurotus ostreatus & Karas et al. (2016) \\
\hline
\end{tabular}


Pant et al. (2006). Besides this, maize processing wastewater, agro-food industry wastes, olive mill waste, distillery wastewater, dairy wastewater and fruit packaging industry effluent have been successfully tested for the cultivation of certain edible mushroom species (Loss et al., 2009; Philippoussis and Diamantopoulou, 2010; Ruiz-Rodriguez et al., 2010; Gothwal et al., 2012; Karas et al., 2016).

\section{Assets in sustainable development}

Besides the benefits of utilizing TAWs in mushroom cultivation, there are a few problems associated with integrating it. There might be the presence of certain heavy metals, toxins, pesticides, persisting aromatic hydrocarbons, etc. Therefore, prior testing and confirmation of their presence are recommended (EPA, 1993). However, the acceptable limits. Table 3 provides Australian Standards recommended by EPA for finished substrate/compost products (Australia Standards, 2012). However, not all kinds of TAWs may contain all these toxic substances in higher amounts, a better example is dairy, bakery and palm oil wastewater, they comprise most of the non-toxic constituents. The EPA recommends that the following Australian Standards be adopted in setting environmental goals and quality parameters for compost products:

- $\quad$ AS 4454-2012 for compost, soil conditioners, and mulches

- AS4419-2003 for foils for landscaping and garden use

- $\quad$ AS 3743-2003 for potting mixes

- $\quad$ AS/NZS 5024 (INT)-2005 for potting mixes, composts, and other matrices: examination for legionellae.

Table 3. Australian Standards recommended by EPA for finished substrate/compost products (Sources: Australian Standards, 2012; EPA, 2019).

\begin{tabular}{ll}
\hline Chemical contaminant & Maximum permissible limit \\
\hline Aldrin & $0.02 \mathrm{mg} / \mathrm{Kg}$ \\
dieldrin & $0.02 \mathrm{mg} / \mathrm{Kg}$ \\
Arsenic & $20.00 \mathrm{mg} / \mathrm{Kg}$ \\
Cadmium & $1.00 \mathrm{mg} / \mathrm{Kg}$ \\
Chromium & $100.00 \mathrm{mg} / \mathrm{Kg}$ \\
Copper & $150.00 \mathrm{mg} / \mathrm{Kg}$ \\
Lead & $150.00 \mathrm{mg} / \mathrm{Kg}$ \\
Mercury & $1.00 \mathrm{mg} / \mathrm{Kg}$ \\
Nickel & $60.00 \mathrm{mg} / \mathrm{Kg}$ \\
Zinc & $300.00 \mathrm{mg} / \mathrm{Kg}$ \\
Glass, metal and rigid plastics & $0.50 \%$ dry matter $(\mathrm{w} / \mathrm{w})$ \\
Plastics-light and flexible or film & $0.05 \%$ dry matter $(w / w)$ \\
\hline
\end{tabular}




\section{Further utilization of spent mushroom substrates}

SMS, which has less lignin due to the digestion process by extra-cellular lignocellulosic enzymes during mushroom production, is merit for biofuel production. The lower lignin content but high nitrogen and ash content make the SMS more easily digested by microbial degraders to yield more reducing sugars. Indeed, the resulting polysaccharides act as a suitable substrate for hydrolysis, since the production of SMS itself has served as a form of pre-treatment. Table 4 provides previously published reports on the utilization of SMS for various purposes. These include biogas production, animal feed for mature castrated male sheep, post-weaning calves feeding, biodiesel production, bioethanol production, reducing sugar production, biofertilizer production, methane production, butanol production, etc. (Kumar et al., 2020).

\section{Conclusion}

Mushroom production represents a source of extra income for farmers and can be grown on a diverse range of lignocellulosic wastes including agricultural residues and agro-based industrial wastes. The spent mushroom substrates have great potential for bioenergy production. The leftover material after cultivation can be used for the generation of biogas, biodiesel, and bioethanol, etc. Non-residual and non-fractional materials may also be used as a fed-stock for composting and using as an effective biofertilizer.

Table 4. Spent mushroom substrate (SMS) used for various purposes.

\begin{tabular}{|c|c|c|}
\hline Spent substrate & Purpose & Reference \\
\hline Wheat straw & Biogas & Bisaria et al. (1990) \\
\hline Wheat straw & $\begin{array}{l}\text { Mature castrated male sheep } \\
\text { feeding }\end{array}$ & $\begin{array}{l}\text { Fazaeli and Masoodi } \\
\text { (2006) }\end{array}$ \\
\hline $\begin{array}{l}\text { Cotton waste-based } \\
\text { substrate }\end{array}$ & Biodiesel production & Kwak et al. (2009) \\
\hline $\begin{array}{l}\text { Hydrolysates of } \\
\text { corncob-based substrate }\end{array}$ & Bioethanol production & Oguri et al. (2011) \\
\hline Sawdust & Post-weaning calves feeding & Kim et al. (2011) \\
\hline Wheat straw & Sugar production & Kapu et al. (2012) \\
\hline What straw & Biogas production & Sonia et al. (2013) \\
\hline Alkali treated wheat straw & $\begin{array}{l}\text { Reducing sugar and biofertilizer } \\
\text { production }\end{array}$ & Zhu et al. (2013) \\
\hline $\begin{array}{l}\text { Dairy manure and wheat } \\
\text { straw }\end{array}$ & Modeling of methane production & Shi et al. (2014) \\
\hline $\begin{array}{l}\text { Yard trimmings and wheat } \\
\text { straw }\end{array}$ & Biogas production & Lin et al. (2014) \\
\hline Wheat straw & Butanol and biodiesel production & Zhu et al. (2016) \\
\hline
\end{tabular}




\section{Acknowledgement}

This research was academically supported by the Department of Zoology and Environmental Science, Gurukula Kangri Vishwavidyalaya, Haridwar, India.

\section{Conflict of interest}

The corresponding author on behalf of all co-authors declares that there is no conflict of interest.

\section{References}

Australia Standards (2012). AS 4454-2012 Composts, soil conditioners and mulches. Published by Standards Australia, AU, pp. 80. https://infostore.saiglobal.com/en-au/standards/as-4454-2012-121773_SAIG_AS_AS_267608 Accessed on 05 October, 2019.

Avni, S., Ezove, N., Hanani, H., Yadid, I., Karpovsky, M., Hayby, H. and Danay, O. (2017). Olive mill waste enhances aGlucan content in the edible mushroom Pleurotus eryngii. International Journal of Molecular Sciences, 18(7): 1564. https:// doi.org/10.3390/ijms18071564

BARC. (2018). Scientists use oil palm waste to cultivate edible mushrooms. Brazilian Agricultural Research Corporation, Ministry of Agriculture, Livestock, and Food Supply. Accessed from https://www.embrapa.br/en/busca-de-noticias//noticia/32958747/cientistas-usam-residuos-do-dende-para-cultivar-cogumelos-comestiveis on 10 November, 2019.

Bellettini, M.B., Fiorda, F.A., Maieves, H.A., Teixeira, G.L., Ávila, S., Hornung, P.S. and Ribani, R.H. (2016). Factors affecting mushroom Pleurotus spp. Saudi Journal of Biological Sciences, 26(4): 633-646. https:// doi.org/10.1016/j.sjbs.2016.12.005

Bisaria, R., Vasudevan, P., Bisaria, V.S. (1990). Utilization of spent agro-residues from mushroom cultivation for biogas production. Applied Microbiology Biotechnology, 33: 607-609. https://doi.org/10.1007/bf00172560

Carrasco, J., Zied, D.C., Pardo, J.E., Preston, G.M. and Pardo-Giménez, A. (2018). Supplementation in mushroom crops and its impact on yield and quality. AMB Express, 8(1): 146. https:// doi.org/10.1186/s13568-018-0678-0

Chanda, A., Gummadidala, P.M. and Gomaa, O.M. (2016). Mycoremediation with mycotoxin producers: a critical perspective. Applied Microbiology and Biotechnology, 100(1): 17-29. https:// doi.org/10.1007/s00253-015-7032-0

Chang, S. and Wasser, S. (2018). Current and future research trends in agricultural and biomedical applications of medicinal mushrooms and mushroom products. International Journal of Medicinal Mushrooms, 1121-1133, https://doi.org/10.1615/ IntJMedMushrooms.2018029378

Covino, S., Stella, T. and Cajthaml, T. (2016). Mycoremediation of organic pollutants: Principles, opportunities, and pitfalls. Fungal Biology, 185-231. https://doi.org/10.1007/978-3-319-42852-9_8

EPA (1993). Environment Protection Act, Minister for Environment and Water: Gazette 22.3.2018 pp. 1256

EPA (2019). Compost guideline. Environment Protection Authority, South Australia, Accessed from http:// www.epa.sa.gov.au/files/4771340_consult_compostguideline.pdf on 01 November, 2019.

Fazaeli, H. and Masoodi, A.R.T. (2006) Spent wheat straw compost of Agaricus bisporus mushroom as ruminant feed. AsianAustralasian Journal of Animal Sciences, 19: 845-851. https://doi.org/10.5713/ajas.2006.845

Gerwien, F., Skrahina, V., Kasper, L., Hube, B. and Brunke, S. (2017). Metals in fungal virulence. FEMS Microbiology Reviews, 42(1): fux050. https://doi.org/10.1093/femsre/fux050

Gothwal, R., Gupta, A., Kumar, A., Sharma, S. and Alappat, B. J. (2012). Feasibility of dairy waste water (DWW) and distillery spent wash (DSW) effluents in increasing the yield potential of Pleurotus flabellatus (PF 1832) and Pleurotus sajor-caju (PS 1610) on bagasse. 3 Biotech, 2(3): 249-257. https://doi.org/10.1007/s13205-012-0053-9 
Grimm, D. and Wösten, H.A. (2018). Mushroom cultivation in the circular economy. Applied Microbiology and Biotechnology, 102(18): 7795-7803. https://doi.org/10.1007/s00253-018-9226-8

Gyenge, B., Kozma, T., Almádi, B., Szarvas, J., Villás, G. and Urvölgyi, M. (2016). Technology innovation in sustainable growing and distribution of king oyster mushroom. Hungarian Agricultural Engineering, (29): 5-10. https://doi.org/10.17676/ hae.2016.29.5

Hanafi, F.H.M., Rezania, S., Taib, S.M., Din, M.F.M., Yamauchi, M., Sakamoto, M. and Ebrahimi, S.S. (2018). Environmentally sustainable applications of agro-based spent mushroom substrate (SMS): an overview. Journal of Material Cycles and Waste Management, 20(3): 1383-1396. https:// doi.org/10.1007/s10163-018-0739-0

Kalmıs, E. and Sargın, S. (2004). Cultivation of two Pleurotus species on wheat straw substrates containing olive mill waste water. International Biodeterioration \& Biodegradation, 53(1): 43-47. https://doi.org/10.1016/j.ibiod.2003.08.002

Kalmis, E., Azbar, N., Yıldız, H. and Kalyoncu, F. (2008). Feasibility of using olive mill effluent (OME) as a wetting agent during the cultivation of oyster mushroom, Pleurotus ostreatus, on wheat straw. Bioresource Technology, 99(1): 164-169. https://doi.org/10.1016/j.biortech.2006.11.042

Kapu, N.U.S., Manning, M., Hurley, T.B., Voigt, J., Cosgrove, D.J. and Romaine, C.P. (2012). Surfactant-assisted pretreatment and enzymatic hydrolysis of spent mushroom compost for the production of sugars. Bioresource Technology, 114: 399-405. https://doi.org/10.1016/j.biortech.2012.02.139

Karas, P.A., Makri, S., Papadopoulou, E.S., Ehaliotis, C., Menkissoglu-Spiroudi, U. and Karpouzas, D.G. (2016). The potential of organic substrates based on mushroom substrate and straw to dissipate fungicides contained in effluents from the fruit-packaging industry-Is there a role for Pleurotus ostreatus?. Ecotoxicology and Environmental Safety, 124: 447-454. https://doi.org/10.1016/j.ecoenv.2015.11.022

Kim, M., Lee, H., Park, J., Kang, S., Choi, Y. (2011) Recycling of fermented sawdust-based oyster mushroom spent substrate as a feed supplement for postweaning calves. Asian-Australasian Journal of Animal Sciences, 24: 493-499. https:// doi.org/10.5713/ajas.2011.10333

Kretschmer, N., Ribbe, L. and Gaese, H. (2002). Wastewater reuse for agriculture. Technology Resource Management E Development-Scientific Contributions for Sustainable Development, 2: 37-64.

Kulshreshtha, S., Mathur, N. and Bhatnagar, P. (2014). Mushroom as a product and their role in mycoremediation. $A M B$ Express, 4(1): 1-29. https:/ / doi.org/10.1186/s13568-014-0029-8

Kumar, V., Singh, J. and Kumar, P. (2018). Adding benefits to phytoremediation of sugar mill effluent by growing water hyacinth (Eichhornia crassipes): Evaluation of biomass for biogas production. Archives of Agriculture and Environmental Science, 3(3): 275-288. https://doi.org/10.26832/24566632.2018.0303011

Kumar, P., Kumar, V., Kumar, S., Singh, J. and Kumar, P. (2020). Bioethanol production from sesame (Sesamum indicum L.) plant residue by combined physical, microbial and chemical pretreatments. Bioresource Technology, 297, 122484.

Kumar, V., Thakur, R.K. and Kumar, P. (2019). Assessment of heavy metals uptake by cauliflower (Brassica oleracea var. botrytis) grown in integrated industrial effluent irrigated soils: A prediction modeling study. Scientia Horticulturae, 257, 108682

Kwak, W.S., Kim, Y.I., Seok, J.S., Oh, Y.K. and Lee, S. M. (2009). Molasses and microbial inoculants improve fermentability and silage quality of cotton waste-based spent mushroom substrate. Bioresource Technology, 100(3): 1471-1473. https:// doi.org/10.1016/j.biortech.2008.07.066

Lin, Y., Ge, X. and Li, Y. (2014). Solid-state anaerobic co-digestion of spent mushroom substrate with yard trimmings and wheat straw for biogas production. Bioresource Technology, 169: 468-474. https://doi.org/10.1016/j.biortech.2014.07.020

Loss, E., Royer, A.R., Barreto-Rodrigues, M. and Baranaa, A.C. (2009) Use of maize wastewater for the cultivation of the Pleurotus spp. mushroom and optimization of its biological efficiency. Journal of Hazardous Materials, 166: 1522-1525. https:// doi.org/10.1016/j.jhazmat.2008.11.014

Migliore, L., Fiori, M., Spadoni, A. and Galli, E. (2012). Biodegradation of oxytetracycline by Pleurotus ostreatus mycelium: a mycoremediation technique. Journal of Hazardous Materials, 215: 227-232. https://doi.org/10.1016/j.jhazmat.2012.02.056

Montoya, S., Orrego, C.E. and Levin, L. (2012). Growth, fruiting and lignocellulolytic enzyme production by the edible mushroom Grifola frondosa (maitake). World Journal of Microbiology and Biotechnology, 28(4): 1533-1541. https:// 
doi.org/10.1007/s11274-011-0957-2

Oguri, E., Takimura, O., Matsushika, A., Inoue, H. and Sawayama, S. (2011). Bioethanol production by Pichia stipitis from enzymatic hydrolysates of corncob-based spent mushroom substrate. Food Science and Technology Research, 17(4): $267-272$. https://doi.org/10.3136/fstr.17.267

Pant, D., Reddy, U.G. and Adholeya, A. (2006). Cultivation of oyster mushrooms on wheat straw and bagasse substrate amended with distillery effluent. World Journal of Microbiology and Biotechnology, 22(3): 267-275. https:// doi.org/10.1007/s11274-005-9031-2

Pedrero, F., Kalavrouziotis, I., Alarcón, J.J., Koukoulakis, P. and Asano, T. (2010). Use of treated municipal wastewater in irrigated agriculture-Review of some practices in Spain and Greece. Agricultural Water Management, 97(9): $1233-1241$. https://doi.org/10.1016/j.agwat.2010.03.003

Phan, C.W. and Sabaratnam, V. (2012). Potential uses of spent mushroom substrate and its associated lignocellulosic enzymes. Applied Microbiology and Biotechnology, 96(4): 863-873. https://doi.org/10.1007/s11274-005-9031-2

Philippoussis, A. and Diamantopoulou, P. (2011) Agro-food industry wastes and agricultural residues conversion into high value products by mushroom cultivation. In: Proceedings of the 7th international conference on mushroom biology and mushroom products (ICMBMP7), France, 4-7 October, pp. 344-356.

Randive, S.D. (2012). Cultivation and study of growth of oyster mushroom on different agricultural waste substrate and its nutrient analysis. Advances in Applied Science Research, 3(4): 1938-1949.

Rattan, S., Parande, A.K., Nagaraju, V.D. and Ghiwari, G.K. (2015). A comprehensive review on utilization of wastewater from coffee processing. Environmental Science and Pollution Research, 22(9): 6461-6472. https://doi.org/10.1007/s11356015-4079-5

Rebah, F.B., Prévost, D., Yezza, A. and Tyagi, R.D. (2007). Agro-industrial waste materials and wastewater sludge for rhizobial inoculant production: a review. Bioresource Technology, 98(18): 3535-3546. https://doi.org/10.1016/ j.biortech.2006.11.066

Royse, D.J., Baars, J. and Tan, Q. (2017). Current overview of mushroom production in the world. Edible and Medicinal Mushrooms: Technology and Applications, 5-13. https://doi.org/10.1002/9781119149446.ch2

Ruiz-Rodriguez, A., Soler-Rivas, C., Polonia, I. and Wichers, H. J. (2010). Effect of olive mill waste (OMW) supplementation to oyster mushrooms substrates on the cultivation parameters and fruiting bodies quality. International Biodeterioration $\mathcal{E}$ Biodegradation, 64(7): 638-645. https://doi.org/10.1016/j.ibiod.2010.07.003

Sadh, P.K., Duhan, S. and Duhan, J.S. (2018). Agro-industrial wastes and their utilization using solid state fermentation: a review. Bioresources and Bioprocessing, 5(1): 1-10. https://doi.org/10.1186/s40643-017-0187-z

Sánchez, C. (2009). Lignocellulosic residues: biodegradation and bioconversion by fungi. Biotechnology Advances, 27(2): 185194. https://doi.org/10.1016/j.biotechadv.2008.11.001

Shi, X.S., Yuan, X.Z., Wang, Y.P., Zeng, S.J., Qiu, Y.L., Guo, R.B. and Wang, L.S. (2014). Modeling of the methane production and $\mathrm{pH}$ value during the anaerobic co-digestion of dairy manure and spent mushroom substrate. Chemical Engineering Journal, 244: 258-263. https:// doi.org/10.1016/j.cej.2014.02.007

Shuval, H. (2012). Water renovation and reuse. (Ed.). Elsevier. pp. 44.

Smith, J.F. (1984). Nutrient transport in the trough system of mushroom culture. Scientia Horticulturae, 24(3-4): 257-264. https://doi.org/10.1016/0304-4238(84)90109-2

Sonia, K., Wati, L., Kant, R., Chourasia, S.K. and Singh, U. (2013). Management of spent mushroom substrate (SMS) through enrichment of biogas plant slurry. Trends in Biosciences, 6(5): 581-591.

Udom, B.E., Nuga, B.O. and Adesodun, J.K. (2016). Water-stable aggregates and aggregate-associated organic carbon and nitrogen after three annual applications of poultry manure and spent mushroom wastes. Applied Soil Ecology, 101: 5-10. https://doi.org/10.1016/j.apsoil.2016.01.007

Valverde, M.E., Hernández-Pérez, T. and Paredes-López, O. (2015). Edible mushrooms: improving human health and promoting quality life. International Journal of Microbiology, 1-10. https://doi.org/10.1155/2015/376387

Wang, D., Sakoda, A. and Suzuki, M. (2001) Biological efficiency and nutritional value of Pleurotus ostreatus cultivated on spent beer grain. Bioresource Technology, 78: 293-300. https://doi.org/10.1016/s0960-8524(01)00002-5 
Zhu, H.J., Liu, J.H., Sun, L.F., Hu, Z.F. and Qiao, J.J. (2013). Combined alkali and acid pretreatment of spent mushroom substrate for reducing sugar and biofertilizer production. Bioresource Technology, 136: 257-266. https://doi.org/10.1016/ j.biortech.2013.02.121

Zhu, Y., Chang, Y., Guan, J., Shanguan, G. and Xin, F. (2016). Butanol production from organosolv treated spent mushroom substrate integrated with in situ biodiesel extraction. Renewable Energy, 96: 656-661. https://doi.org/10.1016/ j.renene.2016.04.048

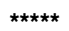

Cite this chapter as: Kumar, V., Goala, M., Kumar, P., Singh, J. and Kumar, P. (2020). Integration of treated agro-based wastewaters (TAWs) management with mushroom cultivation . In: Environmental Degradation: Causes and Remediation Strategies, Volume 1, Eds. Kumar, V., Singh, J. and Kumar, P., pp. 63-75, https://doi.org/10.26832/aesa-2020-edcrs-05 